https://doi.org/10.5817/RPT2017-1-5

\title{
PŘEHLED AKTUÁLNÍ JUDIKATURY I/2017
}

FRANTIŠEK KASL, PAVEL LOUTOCKÝ, JAKUB MÍŠEK, ANNA SLÁNSKÁ, LUCIE STRAKOVÁ, ANNA ŠTEFANIDESOVÁ

\section{ZÁVAZKY Z LICENČNÍ SMLOUVY V PŘÍPADĚ ZRUŠENÍ NEBO NEPORUŠENÍ PATENTU}

Soud: $\quad$ Soudní dvůr Evropské unie

Věc: $\quad$ C-567/14 (Genentech)

Datum: $\quad$ 7. 7. 2016

Dostupnost: curia.europa.eu

V roce 1992 společnost Behringwerke AG udělila společnosti Genentech nevýhradní celosvětovou licenci (smlouva se řídila německým právem) na využívání aktivátoru nezbytného pro výrobu specifických léčiv. Tato technologie byla předmětem dvou patentů v USA a jednoho evropského patentu. Genentech zaplatila za jejich uživání na základě licenční smlouvy jednorázový poplatek; poplatek z komercializace však společnosti Hoechst (ta vstoupila do práv společnosti Behringwerke) nikdy neuhradila.

Na základě rozhodčí doložky rozhodl rozhodce, že společnost Genentech je povinna tento poplatek platit. Společnost Genentech se v řízení hájila tím, že tuto povinnost nemá, jelikož podle licenční smlouvy bylo předpokladem hrazení to, aby byl aktivátor přítomen $\mathrm{v}$ konečném výrobku. ${ }^{1}$ Tento argument však byl odmítnut (což bylo potvrzeno i odvolacím soudem) a povinnost hradit poplatek z minulosti potvrzena. ${ }^{2}$

Bod 32 rozsudku.

2 Společnost Genentech se pak ještě snažila bránit žalobou o zrušení amerických patentů (zrušení má zpětnou účinnost), která však byla zamítnuta (rovněž tímto krokem se snažila společnost vyhnout povinnosti platit poplatky z komercializace). 
V rámci rozhodování odvolacího soudu však vyvstala předběžná otázka, kdy se soud dotazoval na to, zda je v souladu s článkem 101 SFEU nutno shledávat licenční smlouvu související s hrazením poplatků za využívání patentu účinnou i v př́ípadě, že dojde v průběhu plynutí takové smlouvy ke zrušení patentů.

Z předešlé rozhodovací praxe Soudního dvoru Evropské unie (dále jako „SDEU“) vyplynulo, že čl. 101 SFEU nezakazuje uložit smluvně placení poplatku za výhradní užití vynálezu, na který se již nevztahuje patentová ochrana, pokud nabyvatel licence může svobodně tuto smlouvu vypovědět. To je odůvodněno tím, že poplatek je hrazen v souvislosti s obchodním využitím technologie se zárukou, že poskytovatel licence nebude uplatňovat svá práva průmyslového vlastnictví (a jedná se rovněž o smluvní volnost stran). Zejména okolnost, že smlouva může být svobodně ukončena, totiž umožňuje vyloučit, aby hrazení poplatku narušovalo hospodářskou soutěž tím, že omezuje svobodu jednání nabyvatele licence nebo vede $\mathrm{k}$ uzavření trhu. ${ }^{3}$

Soud tak poměrně nepřekvapivě potvrdil svou předešlou rozhodovací praxi a rozhodl, že článek 101 SFEU nebrání tomu, aby na základě takové licenční smlouvy byla nabyvateli licence uložena povinnost platit poplatek za využívání patentované technologie po celou dobu účinnosti této smlouvy v případě zrušení nebo neporušení patentů, které jsou předmětem licence, pokud nabyvatel licence mohl uvedenou smlouvu svobodně ukončit výpovědí s přiměřenou výpovědní lhůtou.

Bod 40 rozsudku. 


\section{ROZLIŠOVACÍ ZPŮSOBILOST OZ JE NUTNÉ ZÍSKAT VE VŠECH ČLENSKÝCH STÁTECH EU}

Soud: $\quad$ Soudní dvůr Evropské unie - Tribunál

Věc: $\quad$ T-112/13 (Mondelez UK Holdings \& Services v. EUIPO)

Datum: $\quad$ 15. 12.2016

Dostupnost: curia.europa.eu

Společnost Société des Produits Nestlé S.A. (dále jako „Nestlé“) je od roku 2002 majitelkou zapsané 3D ochranné známky Evropské unie představované čtyřmi stejnými tyčinkami lichoběžníkového tvaru zarovnanými v řadě a položenými na obdélníkovém podstavci, a to pro výrobky třídy 30 (sladkosti, pekárenské výrobky, pečivo, sušenky, koláče a vafle).

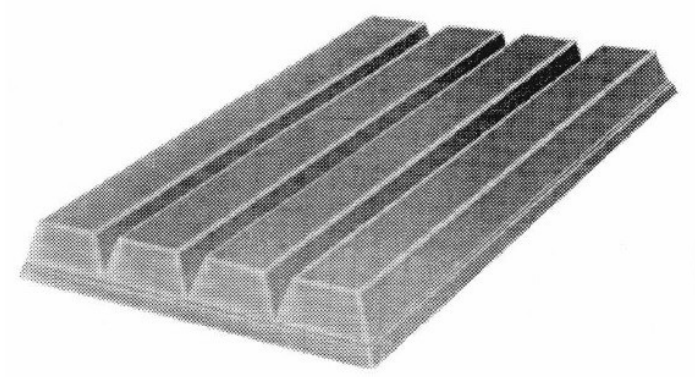

Obr. č. 1: Ochranná známka EU č. zápisu 002632529. Zdroj: Rozsudek Tribunálu ve věci T-112/13.

Společnost Cadbury Holdings Ltd (dnes Mondelez UK Holdings \& Services Ltd, dále jako „Mondelez“) podala v roce 2007 návrh na prohlášení neplatnosti ochranné známky, jemuž Úřad Evropské unie pro duševní vlastnictví (dále „EUIPO“) vyhověl. Nestlé podalo odvolání, kterému přisvědčil Odvolací senát EUIPO. Mondelez podala žalobu na zrušení rozhodnutí odvolacího senátu k Tribunálu Soudního dvora Evropské unie (dále jako „SDEU“).

SDEU se zabýval otázkou rozlišovací způsobilosti tvaru tyčinky Kit Kat jako 3D ochranné známky Evropské unie. 
Při řešení sporu došlo $k$ aplikaci čl. 7 ve spojení s čl. 52 nařízení Rady (ES) č. 207/2009, o ochranné známce Evropské unie.

SDEU ohledně seznamu výrobků konstatoval, že všechny výrobky spadají do jedné kategorie sladkých pochutin, kdy v rámci ní spotřebitelé jednotlivé výrobky vzájemně př́liš neodlišují. Nicméně naznal, že nebylo prokázáno užívání ve vztahu k pekárenským výrobkům, pečivu, koláčům a vaflím. Důkazní materiály se týkaly čokoládové tyčinky Kit Kat, která je optikou SDEU „sušenkou“ nebo „sladkostí“. Kladně posoudil SDEU závěry odvolacího senátu o tom, že je v souladu s rozhodovací praxí prokazování nabytí rozlišovací způsobilosti užíváním označení s jinou ochrannou známkou, kdy takové důkazy pochází $\mathrm{z}$ doby před podáním přihlášky ochranné známky. SDEU se s odvolacím senátem neshodl ohledně určení územní působnosti, na níž se má nabytí rozlišovací způsobilosti prokazovat. EUIPO vycházel z předpokladu, že postačí prokázání rozlišovací způsobilosti u významné části veřejnosti Evropské unie. SDEU však toto kritérium konkretizoval. Rozlišovací způsobilost musí být získána u významné části veřejnosti celé Evropské unie, tedy ve všech státech, které jsou ke dni podání přihlášky jejími členy. Nedostatečné uznání označení jako označení obchodního původu v jedné části území Evropské unie není možné vyvážit vyšší úrovní povědomí v jiné části. Fakt, že byla rozlišovací způsobilost prokázána v 11 členských státech z celkových 15 , byt tvořily téměř $90 \%$ populace Evropské unie, neprokazuje nabytí rozlišovací způsobilosti na území celé Evropské unie.

SDEU zrušil rozhodnutí odvolacího senátu EUIPO, který nyní o věci znovu rozhodne. 


\title{
DATA RETENTION DLE E-PRIVACY SMĚRNICE
}

\author{
Soud: $\quad$ Soudní dvůr Evropské unie \\ Věc: $\quad$ C-203/15 a C-698/15 (Tele2 Sverige) \\ Datum: 21. 12. 2016 \\ Dostupnost: curia.europa.eu
}

V řízení u SDEU došlo ke spojení dvou věcí. V případě věci C-203/15 Tele2 Sverige, švédská společnost poskytující služby elektronických komunikací, v návaznosti na zneplatnění směrnice $2006 / 24 / \mathrm{ES}^{4}$ přestala uchovávat provozní a lokalizační údaje svých zákazníků. Ministerstvo spravedlnosti naopak vyhodnotilo, že švédská právní úprava je souladná s unijní a nařídilo novou povinnost údaje uchovávat. Ve věci C-698/15 podala skupina fyzických osob k Nejvyššímu soudu pro Anglii a Wales podnět na přezkum zákonnosti národní právní úpravy, která zakládala povinnost uchovávat provozní a lokalizační údaje.

Tele2 Sverige podala správní žalobu proti rozhodnutí ministerstva, kterou správní soud ve Stockholmu zamítl. Společnost se odvolala a odvolací soud předložil předběžnou otázku SDEU. V př́ípadě C-698/15 Nejvyšší soud rozhodl, že národní úprava, která zneplatněné směrnici odpovídá, nemůže být proporcionální. Ministr vnitra se proti rozhodnutí odvolal a odvolací soud pro Anglii a Wales předložil SDEU předběžnou otázku.

SDEU se zabýval dvěma otázkami. První, zda je obecná plošná úprava nerozlišující povinnost sbírat a uchovávat provozní a lokalizační údaje pro účely boje s trestnou činností v souladu s právem EU. Druhou, zda směrnice 2002/58/ES brání národní právní úpravě, která umožňuje neomezený přístup vnitrostátních orgánů $\mathrm{k}$ uchovávaným údajům $\mathrm{i}$ bez předchozího soudního přezkumu.

Případ se zabývá aplikací čl. 15 odst. 1 směrnice 2002/58/ES, s ohledem na články 7, 8 a čl. 52 odst. 1 Listiny základních práv EU.

\footnotetext{
4 Tzv. „Data retention směrnice“ byla zneplatněna rozhodnutím SDEU ve věci Digital Rights Ireland (spojené věci C-292/12 a C-594/12).
} 
SDEU argumentačně navazuje na rozhodnutí Digital Rights Ireland. Nejprve konstatoval aplikovatelnost směrnice 2002/58/ES. Připomněl, že čl. 15 umožňuje uchovávat provozní a lokalizační údaje jen za účelem předcházení a šetření trestných činů, a to jen po omezenou dobu a na základě specifikovaných důvodů. V uvedených případech však docházelo k plošnému uchovávání těchto údajů, bez připuštění výjimek a rozlišení různých uživatelů. Šlo tedy fakticky o pravidlo a nikoli výjimku, jak směrnice požadovala. Nebyl tak splněn požadavek nezbytnosti, potřebný pro založení zákonné povinnosti uchovávat údaje. ${ }^{5} \mathrm{~V}$ případě druhé otázky SDEU dovodil, že soudní dohled předcházející přístupu orgánů k údajům je nutný, stejně tak jako následné informování subjektů údajů o zpracování údajů. Jen díky tomu může být zajištěna nezbytná možnost soudního přezkumu.

Rozhodnutí SDEU jednoznačně stanovilo, že čl. 15 směrnice 2002/58/ES, na který se řada národních států spoléhala, nedovoluje takovou právní úpravu, která zakládá povinnost plošného uchovávání provozních a lokalizačních údajů a umožňuje soudně nepodmíněný a předem nekonkretizovaný přístup k nim.

\section{MÍSTNÍ PŘÍSLUŠNOSTI PRO CIVILNÍ NÁROKY PŘI ON-LINE PRODEJI ZBOŽÍ}

Soud: $\quad$ Soudní dvůr Evropské unie

Věc: $\quad$ C-618/15 (Concurrence)

Datum: 21. 12. 2016

Dostupnost: curia.europa.eu

Společnost Concurrence se zabývá maloobchodním prodejem spotřební elektroniky v Paříži a prostřednictvím svého internetového obchodu. Dne 16. 3. 2012 uzavřela společnost Concurrence smlouvu se společností Samsung o selektivní distribuci výrobků značky Samsung, která mimo jiné zapovídala internetový prodej těchto výrobků. Podle společnosti Samsung do-

\footnotetext{
Bod 112 rozhodnutí.
} 
šlo k porušení smlouvy, protože Concurrence nabízela zboží na svém eshopu. Concurrence následně zpochybnila př́ípustnost tohoto ustanovení a poukázala na skutečnost, že někteří distributoři prodávají dotčené výrobky na stránkách společnosti Amazon $^{6}$, přičemž na toto porušení Samsung nijak nereaguje. Následně byl společností Samsung s účinností od 30. 6. 2013 ukončen obchodní vztah se společností Concurrence, která však nadále požadovala dodání zboží. V prosinci 2012 podala společnost Concurrence návrh na předběžné opatření proti společnosti Samsung a téhož dne podala návrh proti společnosti Amazon, kterým se domáhala stažení nabídky sporných výrobků z jejích internetových stránek. Concurrence tvrdila, že nabízení zboží na stránce Amazon ji poškozuje jako autorizovaného distributora.

Soud konstatoval svou nepř́slušnost $\mathrm{v}$ případě internetových stránek společnosti Amazon provozované mimo francouzské území a návrhy proti Amazon zamítl. Concurrence podala odvolání a odvolací soud potvrdil původní rozhodnutí, následovala kasační stížnost $\mathrm{k}$ soudu, který předložil předběžnou otázku Soudnímu dvoru.

Předběžná otázka se týkala určení místní příslušnosti soudů členského státu v kontextu porušení zákazu dalšího prodeje mimo sít selektivní distribuce a na on-line tržišti, $\mathrm{k}$ němuž došlo zveřejněním nabídek $\mathrm{k}$ prodeji na několika internetových stránkách provozovaných $\mathrm{v}$ různých členských státech. SDEU řešil, zda $v$ daném př́ípadě pro určení místní prríslušnosti stačí, že na území státu je nebo byl dostupný on-line obsah, nebo je potřeba existence jiné vazby.

Předběžná otázka se týkala výkladu článku 5 bodu 3 nařízení č. 44/2001 (Brusel I).

SDEU navázal na svoji předchozí judikaturu. ${ }^{7}$ Připomněl, že předmětné ustanovení musí být vykládáno autonomně a restriktivně a „místo, kde došlo nebo může dojít ke škodné události“ označuje místo, kde se škoda mate-

\footnotetext{
6 Bod 16 rozhodnutí. Šlo o stránky provozované na různých doménách prvního řádu, např. Amazon.fr, Amazon.de, Amazon.co.uk a další.

7 Body 25-31 rozhodnutí.
} 
rializovala, a zároveň místo př́icinné události, kde má tato škoda původ; je tedy na volbě žalobce, u kterého soudu podá žalobu.

SDEU judikoval, že skutečnost, že jsou internetové stránky provozovány v jiných členských státech, než je stát, jehož soud rozhoduje o návrhu, je irelevantní, nebot tvrzenou škodu mohly způsobit v obvodu soudu rozhodujícího o návrhu. Místní příslušnost soudu se tedy váže na místo, kde došlo ke škodě, tedy území, na kterém navrhovateli klesl prodej.

\section{STANOVISKO PLÉNA NEJVYŠŠÍHO SOUDU K ELEKTRONICKÉ KOMUNIKACI MEZI SOUDY A ÚČASTNÍKY ŘÍZENÍ}

Soud:

Věc:

Datum:

Dostupnost:
Nejvyšší soud České republiky

Plsn $1 / 2015$

5. 1. 2017

nsoud.cz

Plénum Nejvyššího soudu schválilo stanovisko k podáním činěným v elektronické podobě a $\mathrm{k}$ doručování prováděnému prostřednictvím veřejné datové sítě. Nejdůležitější závěry stanoviska jsou shrnuty dále.

Elektronický nosič (příloha $\mathrm{k}$ datové zprávě) doprovázející samotnou datovou zprávu podanou prostřednictvím informačního systému datových schránek je považován za součást daného podání ve smyslu zákonné definice kladené na elektronické podání $\mathrm{v}$ občanském soudním řádu nebo $\mathrm{v}$ trestním řádu, ledaže z obsahu projevené vůle strany vyplývá něco jiného. ${ }^{8}$

Byl-li z datové schránky (oprávněného) odesilatele odeslán do datové schránky soudu elektronický dokument, který obsahuje podání ve věci samé, považuje se tento dokument (př́loha) za řádně podepsaný (uznávaným elektronickým podpisem), i když samotný dokument elektronicky podepsán není. Pokud byl ale daný dokument odeslán z cizí datové schránky, musí být opatřen uznávaným elektronickým podpisem. ${ }^{9}$

\footnotetext{
Strana 2 stanoviska.

9 Strana 6 stanoviska.
} 
$\mathrm{V}$ př́padě, že bylo podání $\mathrm{v}$ elektronické podobě podepsáno uznávaným elektronickým podpisem, nepoužije se tzv. fikce podpisu podle $\S 18$ odst. 2 zákona č. 300/2008 Sb., o elektronických úkonech a autorizované konverzi dokumentů, ve znění pozdějších předpisů. ${ }^{10}$

Procesní úkon, učiněný prostřednictvím datové schránky se považuje za procesní úkon učiněný písemně a podepsaný osobou, pro kterou byla datová schránka zrrízena. Pokud je takovou osobou právnická osoba, má pak takový úkon učiněný prostřednictvím datové schránky stejnou účinnost, jako kdyby byl proveden osobou oprávněnou jednat za právnickou osobu. ${ }^{11}$

Soud primárně doručuje písemné vyhotovení rozhodnutí (či dalších písemností) do datové schránky $\mathrm{v}$ případě, že adresát má datovou schránku zřízenu. Pokud tomu tak není, přistoupí k jinému způsobu doručení. Soud pak rozhodnutí (či jiné písemnosti) doručuje prostřednictvím datové schránky jen, jestli to povaha dané písemnosti umožňuje. Předpokladem ale je, že adresát má fyzickou osobu oprávněnou nebo pověřenou k prístupu do datové schránky a že nedošlo ke znepř́stupnění datové schránky. Pokud právnická osoba prokáže, že neměla $\mathrm{v}$ době doručení osobu oprávněnou nebo pověřenou $k$ přístupu do datové schránky (a daný stav nebyl zaviněn), nenastanou účinky doručení písemnosti. ${ }^{12}$

Má-li fyzická osoba zřízeno více datových schránek (např. datovou schránku fyzické osoby a zároveň datovou schránku podnikající fyzické osoby), je nutné písemnosti doručovat do té datové schránky, která odpovídá povaze doručované písemnosti. Účinky doručení nastanou ale rovněž doručením do nepř́islušné datové schránky dané fyzické osoby s tím, že okamžik doručení nastává ve chvíli, kdy se do datové schránky přihlásí taková osoba, která má $\mathrm{s}$ ohledem na rozsah svého oprávnění př́stup $\mathrm{k}$ dodaného dokumentu. ${ }^{13}$

Lhůta pro fikci doručení (10 dnů ode dne, kdy byl dokument dodán do datové schránky) se považuje za lhůtu procesní a její běh se počítá v ob-

\footnotetext{
10 Strana 13 stanoviska.

11 Strana 14 stanoviska.

12 Strana 18 stanoviska.

13 Tamtéž.
} 
čanském soudním řízení dle občanského soudního řádu a v trestním řízení dle trestního řádu. ${ }^{14}$

\section{PORUŠENÍ POVINNOSTI PŘIJMOUT NÁLEŽITÁ OPATŘENÍ K OCHRANĚ OSOBNÍCH ÚDAJŮ}

Soud: $\quad$ Nejvyšší správní soud

Věc: $\quad 2$ As $232 / 2016$

Datum: $\quad$ 5. 1.2017

Dostupnost: nssoud.cz

Úřad pro ochranu osobních údajů shledal, že se Vězeňská služba České republiky dopustila správního deliktu, když porušila povinnost přijmout náležitá opatření k ochraně osobních údajů dle $\S 13$ odst. 1 zákona o ochraně osobních údajů, ${ }^{15}$ čímž ve výsledku došlo $\mathrm{k}$ úniku fotografií z kauzy Rath v červnu 2012.

Poté, co byl zamítnut rozklad předsedou Úřadu, podala Vězeňská služba žalobu ve správním soudnictví, kterou Městský soud v Praze zamítl. V kasační stížnosti bylo následně odkazováno na existenci závazných interních pokynů, potřebě př́istupu $\mathrm{k}$ údajům ze strany všech zaměstnanců a úniku údajů pouze $\mathrm{v}$ tomto jediném případě.

Nejvyšší správní soud v rámci rozhodnutí dále rozvinul svůj předchozí výklad $^{16}$ povinností dle $\S 13$ odst. 1,3 a 4 zákona o ochraně osobních údajů.

Soud zdůraznil, že na rozdíl od obecné povinnosti přijmout opatření dle $\S 13$ odst. 1, kde zákon ponechává volbu konkrétních opatření na správci, resp. zpracovateli, musí správce či zpracovatel přijmout opatření dle odstavce třetího a čtvrtého bezvýhradně. Odstavec třetí ukládá povinnost hodnotit rizika, přičemž v rámci možného přistupu neoprávněných osob je

\footnotetext{
14 Tamtéž.

15 Zákon č. 101/2000 Sb., o ochraně osobních údajů a o změně některých zákonů, ve znění pozdějších předpisů.

16 Výklad obsažený mimo jiné v rozsudku ze dne 30. 1. 2013, sp. zn. 7 As 150/2012, publ. pod č. 2845/2013 Sb. NSS.
} 
nutno v souladu s důvodovou zprávou posuzovat též neoprávněný přístup zaměstnance. Odstavec čtvrtý pak ukládá kontrolu přístupu k systémům automatického zpracování osobních údajů. Vězeňská služba tedy nezajistila dostatečná opatření $\mathrm{k}$ ochraně osobních údajů vězněných osob, za situace, kdy k osobním údajům měli bez rozdílu přístup všichni zaměstnanci oprávněni pracovat $s$ daty. Částečné úsilí v podobě vnitřních přepisů pak nepostačuje jako liberační důvod. Samotný únik údajů pak byl pouhým indikátorem nedostatečných opatření. Soud se tedy ztotožnil s názorem předchozí instance a kasační stížnost zamítl.

Rozhodnutí rozšiřuje judikaturní výklad povinností správce osobních údajů ve vztahu k zajištění ochrany údajů a konkretizuje znaky porušení těchto povinností.

\section{DORUČOVÁNÍ DO DATOVÝCH SCHRÁNEK}

$\begin{array}{ll}\text { Soud: } & \text { Vrchní soud v Praze } \\ \text { Věc: } & \text { 103 VSPH 896/2015-198 } \\ \text { Datum: } & \text { 10. 1. 2017 } \\ \text { Dostupnost: } & \text { isir.justice.cz }\end{array}$

Žalovaná společnost SG Equipment Finance Czech Republic s. r. o. byla dne 5. 1. 2015 písemně vyzvána $\mathrm{k}$ vyjádření $\mathrm{k}$ připojené žalobě ve lhůtě 30 dnů od doručení podle § 114b občanského soudního řádu. Žalovaná se $\mathrm{k}$ žalobě ve lhůtě nevyjádřila, ale podala dne 4. 2. 2015 (což byl poslední den lhůty) př́pis, kterým žádala o prodloužení lhůty. Soud prvního stupně neshledal tuto žádost jako důvodnou a vydal rozsudek pro uznání. Rozsudek byl doručen do datové schránky jejího právního zástupce dne 20. 8. 2015, lhůta k odvolání skončila 4. 9. 2015, žalovaná se však odvolala až 7. 9. 2015. Dne 10. 9. 2015 pak žalovaná požádala o prominutí zmeškání lhůty k podání odvolání. Důvodem bylo, že podle software, který používá právní zástupce žalované $\mathrm{k}$ užívání datové schránky, došlo $\mathrm{k}$ doručení datové zprávy s rozsudkem až dne 26. 8. 2015. 
Soud prvního stupně žádosti nevyhověl, podle něj je třeba skutečnost pozdějšího dne doručení (26. 8. 2015) namítat v odvolání proti usnesení o odmítnutí odvolání. Žalovaná se proti tomuto včas odvolala.

Právní otázkou, kterou bylo nutné vyřešit odvolacím soudem, byla především otázka okamžiku, kdy je doručen dokument do sféry adresáta.

Soud v rozhodnutí aplikuje § 17 zákona č. 300/2008 Sb., o elektronických úkonech a autorizované konverzi dokumentů.

Odst. 3 předmětného ustanovení uvádí, že dokument dodaný do datové schránky je doručen okamžikem, kdy se do datové schránky přihlásí osoba, která má $\mathrm{s}$ ohledem na rozsah svého oprávnění př́stup $\mathrm{k}$ dodanému dokumentu. Pro doručování skrze datové schránky navíc platí princip materiálního doručení - tedy zpráva je doručená až když se fakticky dostane do sféry adresáta. Software, který používal zástupce žalované, fungoval na principu, že v okamžiku přihlášení oprávněné osoby stáhl všechny do té chvíle doručené zprávy. V okamžiku doručení rozsudku byla oprávněná osoba již šest minut přihlášena, software tedy rozsudek stáhl až při prríším přihlášení. Tím, že v okamžiku doručení byla oprávněná osoba přihlášena, byla zpráva chybně označena za doručenou, ale adresát se s ní fakticky mohl seznámit až při př́ǐtím přihlášení.

Odvolací soud rozhodl, že zpráva byla do sféry právního zástupce žalované doručena až 26. 8. 2015, a tedy že její návrh na prominutí zmeškání lhůty k odvolání proti rozsudku Krajského soudu v Praze je bezpředmětný, protože odvolání bylo podáno včas. Změnil napadené usnesení tak, že se návrh žalované zamítá. 


\section{PŘÍSTUP K ZADÁVACÍ DOKUMENTACI K ZAKÁZCE „DEKÓDOVÁNÍ ŠIFROVANÝCH DATOVÝCH KOMUNIKACÍ““}

Soud:

Nejvyšší správní soud

Věc:

3 As $58 / 2016$

Datum:

11. 1.2017

Dostupnost:

nssoud.cz

Ministerstvo vnitra zamítlo žádost stěžovatele o poskytnutí kompletní zadávací dokumentace $\mathrm{k}$ nadlimitní veřejné zakázce „Dekódování šifrovaných datových komunikací“ podle $\S 7$ informačního zákona ${ }^{17}$ s odkazem, že se jedná o utajované informace ve smyslu § 2 písm. a) zákona o ochraně utajovaných informací ${ }^{18}$ a bodů 8 a 11 př́slušného nařízení vlády. ${ }^{19}$ Stěžovatel se informací domáhal s odkazem na naléhavou společenskou potřebu odhalit plýtvání veřejnými prostředky, jelikož úkol veřejné zakázky pokládá za zřejmě nesplnitelný.

Ministr vnitra zamítl rozklad. Také navazující správní žaloba byla Městským soudem v Praze zamítnuta, přičemž soud se ztotožnil s názorem, že se jedná o utajované informace, aniž by byl proveden důkaz předmětnou dokumentací. V kasační stížnosti se stěžovatel vymezil vůči podřazení požadovaných informací pod utajované informace, a zdi̊raznil, že soud dokumentaci neposoudil, ale pouze vycházel z tvrzení Ministerstva vnitra.

Stěžejní otázkou bylo posouzení, zda zadávací dokumentace k veřejné zakázce je po formální ${ }^{20}$ a materiální ${ }^{21}$ stránce utajovanou informací ve výše uvedeném smyslu. Pro tento závěr však Nejvyšší správní soud zdůraz-

17 Zákon č. 106/1999 Sb., o svobodném přístupu k informacím, ve znění pozdějších předpisů.

18 Zákon č. 412/2005 Sb., o ochraně utajovaných informací a o bezpečnostní způsobilosti.

19 Nařízení vlády č. 522/2005 Sb., kterým se stanoví seznam utajovaných informací.

20 Předpoklady formální stránky jsou: 1) zaznamenání informace na jakémkoli nosiči, 2) její označení za utajovanou informaci zákonem o ochraně utajovaných informací, a 3) její uvedení v seznamu utajovaných informací obsaženém v nařízení.

${ }^{21}$ Předpokladem materiální stránky utajované informace je i jen potenciální riziko, že by její vyzrazení či zneužití mohlo způsobit zájmu České republiky újmu, či by bylo pro zájem České republiky nevýhodné. 
nil potřebu předchozího seznámení se soudu s vlastním obsahem předmětné dokumentace, čímž přisvědčil stěžovateli. Dle ustálené judikatury Nejvyššího správního soudu musí mít soud vždy možnost seznámit se se všemi podklady, přičemž je zásadně přípustné i dokazování ohledně obsahu utajovaných informací. $^{22}$ Pro posouzení, zda se jedná o utajované informace, se tedy Městský soud musí prvně seznámit s obsahem předmětné dokumentace. $\mathrm{V}$ obecné rovině však Nejvyšší soud vyjádřil názor, že pod pojem operativně pátrací prostředky, který je užit v bodech 8 a 11 nařízení vlády, nelze podřadit sledování elektronické komunikace, jelikož výčet těchto prostředků v ustanovení § 158b odst. 1 trestního řádu je taxativní. Připustil tedy pochybnost ohledně řádného zdůvodnění podřazení předmětné dokumentace pod utajované informace.

Případ otevírá zajímavé otázky ohledně rozsahu užívání institutu utajovaných informací, resp. rozsahu práva na přístup $\mathrm{k}$ informacím $\mathrm{v}$ rámci kontroly dobré správy ze strany veřejnosti.

\section{NÁHRADA ŠKODY V AUTORSKÉM PRÁVU}

Soud: $\quad$ Soudní dvůr Evropské unie

Věc: $\quad$ C-367/15 (Stowarzyszenie Oławska Telewizja Kablowa)

Datum: $\quad 25.1 .2017$

Dostupnost: curia.europa.eu

Dne 30. prosince 1998 byla rozvázána licenční smlouva mezi organizací kolektivní správy SPF a sdružením OTK, které vysílá televizní programy v polské Olavě. Předmětem smlouvy byla pravidla odměňování za uživání chráněných děl. OTK i nadále užívala autorská díla a pro určení odměny, která má být zaplacena, se obrátila na komisi pro autorská práva. Odměna měla být vypočítána jako $1,6 \%$ z čistého př́immu bez DPH, sdružení OTK vyplatilo SFP samostatně vypočítanou částku 34 312,69 PLN, s čímž SPF nesouhlasila a začala se domáhat náhrady 390 337,50 PLN plus úroky.

${ }^{22}$ Soud cituje rozsudky ze dne 24. 4. 2008, č.j. 2 As 31/2007-107, ze dne 24. 4. 2008, č.j. 2 As 41/2007-58 a ze dne 25.11.2011, č.j. 7 As 31/2011-101 a také usnesení rozšířeného senátu ze dne 1. 3. 2016, č.j. 4 As 1/2015-40. 
Soudní dvůr Evropské unie zodpovídal předběžnou otázku podanou polským Nejvyšším soudem, který v rámci kasačního opravného prostředku prováděl třetí přezkum předmětné věci.

Podstatou předběžné otázky bylo, zda je v souladu se směrnicí 2004/48/ES, aby si nositel majetkových práv mohl vybrat, zda se bude domáhat náhrady škody, která mu vznikla na základě obecných zásad, anebo aby mu byl uhrazen dvojnásobek či trojnásobek př́slušné odměny, aniž by musel prokazovat škodu a př́činnou souvislost mezi škodou a událostí vedoucí $\mathrm{k}$ porušení práv.

Čl. 79 odst. 1 polského zákona o autorských právech stanoví, že nositel majetkových práv se může domáhat náhrady škody a) na základě obecných zásad, nebo b) dvojnásobku či trojnásobku odměny. Dle čl. 1 odst. 1 dohody TRIPS mohou členské státy zavést rozsáhlejší ochranu, než tato dohoda vyžaduje. Směrnice 2004/48/ES pak stanoví, že při náhradě škody porušovatelem, který o porušení věděl, nebo mohl vědět, je nutno zohlednit všechna př́slušná hlediska (ušlý zisk, neoprávněné zisky atp.), alternativně může být odměna odvozena od licenčních poplatků, které měly být zaplaceny.

SDEU zjištoval, zda musí být směrnice 2004/48/ES vykládána tak, že brání stávající polské úpravě. Dle odůvodnění má být užívána tak, aby nebyly dotčeny vnitrostátní prostředky ochrany, které mohou být pro nositele práv výhodnější; což vyplývá i z mezinárodních smluv. Ani to, že by odškodnění na základě dvojnásobku poplatku nebylo přímo úměrné škodě, není překážkou, nebot se jedná o inherentní charakteristiku paušálního odškodnění.

SDEU rozhodl, že čl. 13 směrnice 2004/48/ES musí být vykládán tak, že nebrání takové vnitrostátní úpravě, podle které může nositel majetkových práv požadovat bud’ náhradu škody, anebo platbu dvojnásobku či trojnásobku odměny, která by musela být uhrazena $\mathrm{v}$ př́padě udělení oprávnění k užívání příslušného díla, a to aniž by musel prokazovat skutečnou škodu. 


\section{NEZISKOVÁ ORGANIZACE NENÍ ODPOVĚDNÁ ZA HANLIVÉ ANONYMNÍ PŘÍSPĚVKY NA JEJÍM BLOGU}

Soud: $\quad$ Evropský soud pro lidská práva

Věc: $\quad$ Pihl proti Švédsku, č. 74742/14

Datum: $\quad$ 7.2.2017

Dostupnost: HUDOC

O panu Pihlovi byl pod článkem na blogu malé neziskové organizace vložen anonymní hanlivý komentář. Po výzvě stěžovatele byl příspěvek další den odstraněn a byla zveřejněna omluva. Dle stěžovatele se však komentář stále objevoval $\mathrm{v}$ internetových vyhledávačích.

Stěžovatel žaloval, s ohledem na anonymitu původce, organizaci provozující blog o symbolické zadostiučinění za pomluvu. Soudy prvního i druhého stupně připustily existenci znaků pomluvy, neshledaly však v jednání organizace porušení odpovídající povinnosti. Dovolací instance pak dovolání odmítla. Stěžovatel podal žádost ke švédskému kancléři spravedlnosti (Justitiekanslern) o náhradu škody za neposkytnutí soudní ochrany dle článku 8 Evropské úmluvy o ochraně lidských práv garantující právo na respektování soukromého a rodinného života. Žádost byla zamítnuta s ohledem na potřebu rovnováhy s právem na svobodu projevu dle článku 10 Úmluvy, tak jak bylo dovozeno v rozhodnutí Velkého senátu ESLP ve věci Delfi AS proti Estonsku. ${ }^{23}$ Pan Pihl následně podal stížnost k ESLP pro porušení článku 8 Úmluvy.

Soud při posouzení věci zdůraznil, že ačkoliv je pojem „soukromý život“ nutno na základě jeho předchozí judikatury vykládat široce, tedy včetně ochrany pověsti dané osoby, ${ }^{24}$ musí pro aplikaci ochrany dle článku 8 Úmluvy dojít $\mathrm{k}$ útoku určité míry závažnosti, který musí být veden způsobem projevujícím zaujatost proti požívání práva na úctu $\mathrm{k}$ soukromému

${ }^{23}$ Rozhodnutí Evropského soudu pro lidská práva ze dne 10. ř́jna 2013 ve věci Delfi AS proti Estonsku, č. 64569/09.

${ }^{24}$ Soud odkazuje na svá rozhodnutí ve věcech Magyar Tartalomszolgáltatók Egyesülete and Index.hu Zrt proti Mad'arsku, č. 22947/13, § 57, a Pfeifer proti Rakousku, č. 12556/03, $\S 35$. 
životu danou osobou. ${ }^{25}$ Soud také přímo odkázal na své závěry ve věcech Delfi AS proti Estonsku a Axel Springer AG proti Německu. ${ }^{26} \mathrm{~V}$ předmětné věci se tedy ztotožnil se závěry národních soudů, že sporný komentář sice obsahoval prvky pomluvy, ale nedosahoval intenzity podněcování k nenávisti či násili. ${ }^{27}$ Jádrem stížnosti však bylo, zda národní soudní soustava poskytla stěžovateli adekvátní ochranu v souladu s požadavky Úmluvy. Zde soud souladně se závěry švédského kancléře odkázal na argumentaci ve věci Delfi AS proti Estonsku a na potřebu hledání rovnováhy mezi ochranou soukromého života dle článku 8 Úmluvy a svobodou projevu dle článku 10 Úmluvy. Soud při posouzení věci mimo jiné přiznal význam skutečnosti, že se u povinného subjektu jednalo o malou neziskovou organizaci. Ve vztahu $\mathrm{k}$ dostupnosti komentáře pomocí vyhledávačů pak soud odkázal stěžovatele na možnost využít práva na zapomnění. ${ }^{28}$ Soud tedy dospěl $\mathrm{k}$ závěru, že národní soudy jednaly v rámci svého prostoru pro uvážení a nalezly spravedlivou rovnováhu mezi právy chráněnými Úmluvou. ${ }^{29}$ Stížnost byla tudíž jednomyslně prohlášena za nepřípustnou pro zjevnou nedůvodnost.

Rozhodnutí potvrzuje závěry z rozhodnutí ve věci Delfi AS proti Estonsku a rozšiřuje korpus judikaturního výkladu právní ochrany dle článku 8 Úmluvy.

${ }^{25}$ Bod 24 rozhodnutí. „However, in order for Article 8 to come into play, the attack on personal honour and reputation must attain a certain level of seriousness and must have been carried out in a manner causing prejudice to personal enjoyment of the right to respect for private life." (Překlad autora).

${ }^{26}$ Soud odkazuje na svá rozhodnutí ve věci Delfi AS proti Estonsku, § 137, a Axel Springer AG proti Německu, č. 39954/08, § 83.

27 Bod 25 rozhodnutí.

${ }^{28}$ Bod 33 rozhodnutí. Soud odkazuje na rozhodnutí Soudního dvora Evropské unie ze dne 13. května 2014, ve věci Google Spain a Google, sp. zn. C-131/12.

${ }^{29}$ Bod 37 rozhodnutí. 


\section{CENZURA INTERNETU PROSTŘEDNICTVÍM ZÁKONA O HAZARDNÍCH HRÁCH}

Soud: $\quad$ Ústavní soud České republiky

Věc: $\quad$ Pl. ÚS 28/16

Datum: $\quad$ 14. 2. 2017

Dostupnost: nalus.usoud.cz

Skupina 21 senátorů podala $\mathrm{k}$ Ústavnímu soudu návrh na zrušení některých ustanovení zákona o hazardních hrách (186/2016 Sb.) s odůvodněním, že může dojít $\mathrm{k}$ cenzuře internetu, ustanovení jsou nejasně formulována a může rovněž docházet $\mathrm{k}$ omezování svobody podnikání.

Problematická ustanovení § 82, 84 a 123 odst. 5. § 82 a 84 stanovují mechanismus pro blokaci nepovolených internetových her. Jedná se o možnost zablokovat př́ślušnou stránku, prostřednictvím které lze přistoupit k tzv. nepovoleným hrám. Ministerstvo financí vede seznam nepovolených her a ukládá povinnost "poskytovatelům připojení k internetu" na území České republiky zamezit v př́stupu k „internetovým stránkám“, které jsou na tomto seznamu uvedeny. § 123 odst. 5 pak zavádí správně-deliktní odpovědnost poskytovatele za nesplnění výše popsané povinnosti.

Ústavní soud ve svém odůvodnění zdůraznil, že se nemůže jednat o "cenzuru", když je blokování možné jen v nezbytném rozsahu a vylučuje zásah do ostatního (legálního) obsahu. ${ }^{30} \mathrm{Je}$ tak nutno pamatovat rovněž na základní účel a smysl zákona a nelze vytrhnou př́slušná ustanovení z kontextu a rozšiřovat jejich dopad. Úprava dané problematiky je účelná proto, že nelegální hry jsou pravidelně nabízeny ze zahraničí, často záměrně či dokonce jen formálně, právě proto, aby byli provozovatelé obtížně dostižitelní kontrolními orgány. ${ }^{31}$ Namítáno bylo dále nevhodné vymezení

\footnotetext{
30 Bod 30 nálezu.

31 Bod 32 nálezu.
} 
pojmů „poskytovatelé připojení $\mathrm{k}$ internetu“32 a „internetové stránky““33. Pojem poskytovatele připojení $\mathrm{k}$ internetu Ústavní soud vnímá jako subkategorii poskytovatelů služeb informační společnosti ve smyslu § 2 písm. a) a d) zákona o některých službách informační společnosti. ${ }^{34}$ Blokace se pak má týkat výhradně takových internetových stránek, které umožňují přístup k nelegálním hazardním hrám, nikoli např. těch, které obsahují pouze reklamu na nelegální hazardní hry. ${ }^{35}$ Detailnější úprava by se patrně ukázala jako nefunkční, protože nelze dané otázky řešit kazuistickou úpravou. ${ }^{36}$

Je nutno podotknout, že dikci předmětných ustanovení nelze považovat za nejpreciznější, Ústavní soud dal však poměrně jasně najevo, že daný problém nedosahuje rozporu s ústavním pořádkem i vzhledem $\mathrm{k}$ nutnosti respektovat základní principy a účel zákona.

Ústavní soud tak návrh v celém rozsahu zamítl.

\section{ZÁSAH DO MAJETKOVÝCH PRÁV AUTORSKÝCH VYSÍLÁNÍM}

Soud: $\quad$ Soudní dvůr Evropské unie

Věc: $\quad$ C-275/15 (ITV Broadcasting)

Datum: $\quad$ 1. 3. 2017

Dostupnost: curia.europa.eu

Společnosti ITV Broadcasting Limited a další podaly žalobu na společnosti TVCatchup Limited, v insolvenčním řízení (dále jen „TVC“), TVCatchup (UK) Limited (dále jen „TVC UK“) a Media Resources Limited z důvodu, že žalované širíily prostřednictvím internetu televizní vysílání žalobkyň, což žalobkyně považovaly za zásah do jejich autorských práv. Žalované poskytovaly internetové služby, které spočívaly v šiřrení televizního vysílání; díky těmto službám mohli uživatelé „živě“ přijímat bezplatné televizní vysílání.

${ }^{32}$ Pojem poskytovatele připojení $\mathrm{k}$ internetu by dle navrhovatelů mohl být chápán př́liš široce.

${ }^{33} \mathrm{Z}$ toho dle navrhovatelů nemusí být jasné, zda má být blokováno doménové jméno jako celek nebo doménové jméno nižšího řádu.

${ }^{34}$ Bod 50 nálezu.

35 Bod 53 nálezu.

${ }^{36}$ Bod 50 nálezu. 
Žalobkyně podaly žalobu k Nejvyššímu soudu pro Anglii a Wales pro porušení autorských práv, po rozsudku tohoto soudu podaly žalobkyně odvolání. Odvolací soud se rozhodl přerušit řízení a položil SDEU pět předběžných otázek, ten se nakonec zabýval pouze třetí otázkou s tím, že odpovědi na ostatní otázky po zodpovězení té třetí nejsou třeba.

Otázka, kterou se SDEU zabýval, se týkala rozsahu aplikace směrnice 2001/29 v kontextu přístupu ke kabelu vysílacích služeb, a jejího vztahu k vnitrostátnímu předpisu (Copyright, Designs and Patents Act 1988 CDPA), dle kterého autorské právo $\mathrm{k}$ jakémukoli dílu zahrnutému v obsahu vysílání není porušeno, pokud a dokud je uvedený obsah vysílán proto, aby byl přijímán v oblasti, kde je dále přenášen pomocí kabelu.

SDEU interpretoval čl. 9 směrnice 2001/29/ES, o harmonizaci určitých aspektů autorského práva.

SDEU v rámci odpovědi na předběžnou otázku podotkl, že hlavním cílem směrnice 2001/29 je zavedení vysoké úrovně ochrany autorů a že bez souhlasu autora není takový další přenos (jako je internetový streaming) dovolen, pokud se na něj nevztahuje článek 5 této směrnice, kde lze najít taxativní výčet výjimek. ${ }^{37}$

SDEU judikoval, že dle směrnice 2001/29 nezáleží, jestli chráněná díla byla vysílána na televizních kanálech, které podléhají veřejnoprávním povinnostem. Vnitrostátní úprava, tak jak je obsažena v CDPA, podle Soudního dvora nespadá pod aplikaci článku 9 směrnice 2001/29 a není tedy tímto ustanovením dovolena. ${ }^{38}$

37 Bod 27 rozhodnutí.

38 Bod 29 rozhodnutí. 


\section{PŘESHRANIČNÍ POSKYTOVÁNÍ ÚČASTNICKÝCH SEZNAMŮ}

Soud: Soudní dvůr Evropské unie

Věc: $\quad$ C-536/15 (Tele2 Netherlands)

Datum: $\quad$ 15. 3. 2017

Dostupnost: curia.europa.eu

Belgická společnost EDA, nabízející informační služby o účastnických číslech a účastnické seznamy dostupné v Belgii, požádala společnosti přidělující telefonní čísla účastníkům v Nizozemsku, o poskytnutí údajů o jejich účastnících. Po opakovaném odmítnutí se obrátila na nizozemský národní regulační orgán ACM, který rozhodl, že nizozemské společnosti jsou povinny zpř́stupnit EDA údaje o svých účastnících. Dále určil, že tyto společnosti rovněž musí zajistit, aby souhlas účastníků se zpracováním údajů, který si obstarávají při uzavírání smluv, umožnil zveřejnění těchto údajů $\mathrm{v}$ jakémkoli standardním telefonním seznamu a v jakékoli databázi účastníků používané pro účely standardní informační služby o účastnických číslech.

Nizozemské společnosti podaly proti rozhodnutí ACM žalobu u nizozemského odvolacího soudu pro správní spory $\mathrm{v}$ hospodářské oblasti, který položil SDEU předběžné otázky.

První předběžná otázka zněla, zda je nezbytné interpretovat směrnici 2002/22/ES, o univerzální službě tak, že společnosti přidělující telefonní čísla musí poskytnout na základě žádosti informace o účastnících i podniku, který sídlí v jiném členském státě. Druhá otázka se dotazovala, zda může společnost, která přiděluje telefonní čísla, a má tedy povinnost žádat své účastníky o souhlas, dělat $\mathrm{v}$ žádosti o souhlas rozdíly dle toho, ve kterém členském státě operuje žadatel o tyto údaje.

Otázky se týkají čl. 25 odst. 2 směrnice 2002/22/ES. V návaznosti na její čl. 25 odst. 5 je pak aplikován rovněž čl. 12 směrnice 2002/58/ES, o soukromí a elektronických komunikacích. 
SDEU ve své argumentaci přímo navazuje na své rozhodnutí ve věci Deutsche Telekom. ${ }^{39}$ Cílem směrnice 2002/22/ES je zajištění přístupu k veřejně dostupným službám v dobré kvalitě v celé EU. ${ }^{40}$ Čl. 25 odst. 2 směrnice pak vyžaduje, aby podniky přidělující telefonní čísla účastníkům vyhověly všem oprávněným žádostem o poskytnutí dat. Interpretace, která by na základě geografického umístění žadatele a jeho působení zabraňovala poskytnutí dat tak není přijatelná. V případě druhé otázky SDEU uvádí, že řádně informovaný souhlas účastníka o předávání jeho údajů třetím osobám za účelem jejich zveřejnění v účastnických seznamech je limitován právě a pouze tímto účelem a není jej proto možné dále omezit teritoriálně.

SDEU stanovil s poukazem na to, že poskytování předmětných údajů probíhá „, široce harmonizovaném a vymezeném právním rámci umožňujícím $v$ celé Unii zajistit stejné dodržování požadavků v oblasti ochrany osobních údajư “41 ${ }^{41}$ že žádosti o účastnická data je třeba vyhovět i tehdy, když žadatel působí v jiném státě Unie a stejně tak, že souhlas se zpracováním těchto údajů není možné omezit na jednu jurisdikci.

\section{SDĚLOVÁNÍ DÍLA VEŘEJNOSTI PROSTŘEDNICTVÍM ODKAZU}

Soud: Soudní dvůr Evropské unie

Věc: C-527/15 (Stichting Brein)

Datum: 26. dubna 2017

Dostupnost: curia.europa.eu

Jack Frederick Wullems v Nizozemí prodával multimediální přehrávač „filmspeler“, který umožňuje přenos obrazu a zvuku na obrazovku. Jeho součástí byl software s doplňky („add-ons“), které přesměrovávají uživatele na stránky, na kterých jsou chráněná díla zpřístupňována bez svolení nositelů autorského práva. Nizozemská společnost Stichting Brein, zaměřená na ochranu zájmů nositelů autorských práv, vyzvala Wullemse k zastavení prodeje přehrávače.

\footnotetext{
39 Rozhodnutí SDEU ze dne 5. května 2011, ve věci C-543/09.

40 Bod 26 rozhodnutí, dále pak body 34-36 rozhodnutí.

41 Bod 38 rozhodnutí.
} 
Stichting Brein předložila věc prvostupňovému soudu, kdy navrhla, aby bylo Wullemsovi nařízeno ukončení prodeje přehrávačů nebo ukončení nabídky odkazů, které poskytují uživatelům neoprávněný přístup k autorským dílům. Nizozemský soud se obrátil s předběžnou otázkou na SDEU.

SDEU se zabýval čtyřmi otázkami. Podstatou první a druhé otázky bylo, zda musí být pojem „sdělování díla veřejnosti“ vykládán tak, že zahrnuje prodej přehrávače s doplňky s odkazy na autorskoprávně chráněná díla, zpřístupněná bez svolení nositelů práv. Podstatou třetí a čtvrté otázky bylo, zda streamování na předmětném přehrávači lze vykládat jako dočasné rozmnožování, vyňatého z práva na rozmnožování.

Případ se zabývá výkladem čl. 3 odst. 1 a čl. 5 odst. 1 směrnice 2001/29/ES.

SDEU v tomto rozsudku navazuje na dřívější rozhodnutí ohledně sdělování díla veřejnosti, zejm. rozsudek Svensson, BestWater, GS Media, Reha Training, SGAE a další. ${ }^{42}$ SDEU zdůraznil, že pojem „sdělování veřejnosti“ předpokládá individuální posouzení a zahrnuje dva kumulativní prvky sdělování a veřejnost. Dále připomněl, že pro kvalifikaci „sdělování veřejnosti“ je třeba vzít v úvahu, zda je dílo sdělování odlišnou technologií než doposavad, případně veřejnosti, která nebyla pưvodně brána $\mathrm{v}$ potaz („nová veřejnost“). $\mathrm{V}$ případě prodeje multimediálního přehrávače jde o poskytování přímého přístupu uživatelům, nebot̉ se nejedná o pouhé poskytnutí fyzického zařízení, ale zařízení, které již integrálně obsahuje software, který přenos chráněných děl umožňuje. ${ }^{43}$ SDEU dále uvedl, že vzhledem k tomu, že se nejednalo o užití, k jakému byl nositelem práv udělen souhlas, není možné považovat streamování děl za podléhající výjimce pro dočasné rozmnožení. ${ }^{44}$

SDEU došel k závěru, že čl. 3 odst. 1 směrnice 2001/29/ES musí být vykládán tak, že „sdělování veřejnosti“ zahrnuje i prodej zařízení, jehož součástí je nainstalovaný software s odkazy na stránky s neoprávněně zveřejněnými autorskými díly. Dále judikoval, že streamování díla skrze multimedi-

\footnotetext{
42 Body 25-34 rozhodnutí.

43 Body 41-42 rozhodnutí.

44 Bod 66 a následující rozhodnutí.
} 
ální přehrávač nelze považovat za dočasné úkony rozmnožení dle čl. 5 odst. 1 a 5 směrnice 2001/29/ES.

Toto dílo lze užít v souladu s licenčními podmínkami Creative Commons BY-SA 4.0 International (http://creativecommons.org/licenses/by-sa/4.0/legalcode). 